\title{
OKOLJSKA ETIKA IN IZOBRAŽEVANJE ZA TRAJNOSTNI RAZVOJ
}

\section{POVZETEK}

Članek obravnava danes še kako aktualno vprašanje trajnostnega razvoja in meje rasti znotraj prevladujoče paradigme stalnega gospodarskega razvoja. Človeštvo se je znašlo pred težko odločitvijo, kako naprej, saj se nekatere posledice sedanjega antropocentričnega in netrajnostnega razvoja odražajo tako na naravnem okolju kot tudi na družbi. Ne glede na občasne gospodarske krize pomeni dosedanji gospodarski razvoj resno grožnjo prihodnjim rodovom, in to ne le človeškim. Zakon entropije je univerzalni zakon vesolja, ki mu tudi človek na Zemlji ne more ubežati. Dokazano je, da je večji del posledic, ki jih v okolju zaznavamo danes, antropogenega izvora, kar ne nazadnje potrjujejo tudi mnoge študije. Očitno je torej, da bo človek moral spremeniti del svojih ravnanj, predvsem pa temeljito premisliti svoj odnos do stalne gospodarske rasti ter njenih dobrih in slabih posledic. Je morda rešitev nova ekološka etika, ki ne bo antropocentrična, ampak predvsem intrinzična - torej etika, ki ji trajnostni (uravnotežen, sonaraven) razvoj ne bo cilj, ampak sredstvo za dosego cilja? Bo morda pot do etike, ki bo odgovorno ravnala z okoljem in vsemi živimi bitji, krajša, ko bomo izkušnje starejših generacij prek ustreznega izobraževalnega koncepta prenašali na mlajše rodove? Morda. Na srečo so ti rodovi, ki so še kako dojemljivi za »novo" okoljsko/ekološko etiko, že med nami, saj vse skupaj povezuje usoda tega časa in prostora. To ni le naša osebna pravica in dolžnost, temveč, kot je razvidno iz članka, nas k odgovornemu ravnanju z okoljem obvezujejo tudi številni mednarodni dogovori.

Ključne besede: ekonomska rast, meje rasti, entropija, trajnostni razvoj, biotska pestrost, antropocentrična etika, ekološka etika, intrinzičen odnos do narave, medgeneracijska solidarnost, javno mnenje, izobraževanje za trajnostni razvoj.

\section{ENVIRONMENTAL ETHICS AND EDUCATION FOR SUSTAINABLE DEVELOPMENT - ABSTRACT}

The subject of this article - sustainable development and limits to growth within the dominant paradigm of constant economic growth - is an urgent issue today. Mankind is facing a great dilemma regarding the future, as certain effects of the current anthropocentric and non-sustainable development have become apparent in the environment and nature as well as in the human society. The economic development is, despite occasional economic downturns, a serious threat for the future of all life on the planet, not only human beings. The entropy law is universal; it applies to the entire universe, including the people on the Earth. It has been proved by many research studies that the majority of the effects we can observe in the environment are of anthropogenic origin. It is obvious that humans will have to change their practices to a certain extent and, above all, reconsider their attitude to constant economic growth and the effects (good or bad) it entails. The author suggests that a solution to this problems could be in the new ecological ethics, which is intrinsic and no longer anthropocentric, the ethics that will see sustainable (balanced and close to nature) development not as a goal in itself but as a means to reach the set goals. We could perhaps shorten the path to acceptance of this kind of ethics, which fosters responsibility towards the environment, people and all living creatures, if we knew how to pass on the experience of older generations to today's youth by using a suitable educational approach. Luckily, the young generations, who are living with us here and now and sharing the fate of our time and space, are extremely perceptive of the »new environmental/ecological ethics. To embrace it is more than just our individual right and obligation; we are, as the article states, »authorised « and bound to do so by a number of international treaties.

Keywords: environmental ethics, ecological ethics, adult education, lifelong education, sustainable development.

UDK: 374.7:502.131.1

\section{UVOD}

Živimo v času, ko je ekonomija zavladala kot prevladujoča oblika zavesti in prakse. Homo erectus se je prek homo fabra uspešno prelevil v homo oeconomicusa, ki obvladuje večji del planeta Zemlja. Marxovo spoznanje, da zavest določa ekonomijo, in ne obratno, se je dokončno uveljavilo; ekonomija je postala prevladujoča in vseobsegajoča oblika zavesti ter glavni 
motiv človekovega osebnega in družbenega življenja. Z razvito ekonomijo ni dosežena le visoka raven gospodarskega razvoja, temveč Človek je postal
žrtev kapitala in
njegovih zakonov. tudi visoka stopnja človekove alienacije ali odtujitve od lastnega bistva. Tudi človekova zavest se je popredmetila. Kapitalizem je namreč tudi človeka spremenil v blago, ki ima veliko uporabno in majhno menjalno vrednost - tudi človekova vrednost (intrinzična) hitro pada. Z vse večjim udejanjanjem in vrednotenjem človeka narašča tudi njegovo razvrednotenje. Človek je z razvojem ekonomije razvrednotil samega sebe, odtujil se je od narave kot vira, ki ga potrebuje za svoj lastni obstoj.

\section{PROBLEM PARADIGME NENEHNE RASTI}

Ekonomija kot način gospodarjenja je temelj za sodobno družbo in njen obstoj. Zato ni čudno, da je skoraj vsem vladam po svetu skupno prepričanje, da je ključ napredka gospodarska rast oziroma je ta že vse od konca druge svetovne vojne najpomembnejši cilj politikov in ekonomistov po vsem svetu. Velika gospodarska rast krepi nacionalni ponos: če gospodarske rasti ni, se vsi sprašujejo, kako jo ponovno oživiti in kje so naredili napako. Toda družbe kljub desetletjem nenehne rasti niso postale niti srečnejše niti zadovoljnejše s svojim življenjem. Heglova misel, ki govori, da napredek uma (tehnike, znanosti) še ne pomeni večje sreče, je ponovno doživela potrditev. Še več, nevzdržnost sedanje potrošnje postavlja pod vprašaj nekatera temeljna prepričanja o tem, kako živimo in kakšna usoda nas čaka.

Svetovno gospodarstvo je danes skoraj petkrat večje, kot je bilo pred pol stoletja. Če bo z enako stopnjo naraščalo še naprej, bo do leta 2100 večje za 80-krat. Seveda je treba računati z vse prodornejšimi azijskimi državami, kot so Kitajska, Indija in druge.
Prvo resno opozorilo, da neomejen in neškodljiv razvoj ne bo več mogoč, je prišlo leta 1972. Takrat so namreč Donnela in Dennis Meadows ter njuni sodelavci z Inštituta za tehnologijo iz Massachusettsa izdali poročilo »Meje rasti« (The Limits to Growth) za Rimski klub. V poročilu so si zastavili več vprašanj $\mathrm{v}$ zvezi $\mathrm{z}$ eksponentno rastjo svetovnega gospodarstva, prebivalstva in porabo virov od industrijske revolucije naprej. Posameznike (npr. Rifkin, 1980), ki se ukvarjajo z vprašanjem možnosti nadaljnjega razvoja človeštva, in različne strokovne kroge vse bolj preveva dilema oziroma strah, da so te možnosti vedno bolj omejene. Če so prej govorili o dilemah glede možnosti pomanjkanja nekaterih industrijskih surovin in energetskih virov, pa zdaj v ospredje vedno bolj stopa bojazen, da se meje civilizaciji postavljajo $\mathrm{z}$ nevarnostjo entropije in $\mathrm{s}$ tem vseh oblik onesnaževanja. Prav s tem vprašanjem se povezuje večina dilem glede možnosti nadaljevanja t. i. tehnološke paradigme razvoja. Nicholas Stern je težave, v katerih se je planet znašel zaradi prekomernega kopičenja $\mathrm{CO}_{2} \mathrm{v}$ atmosferi od začetka industrijske revolucije (kar 70 odstotkov te količine sta prispevali Evropa in Severna Amerika), imenoval »največji neuspeh trga vseh časov«. Vera v paradigmo o stalni eksponencialni rasti je postala vprašljiva. Človek je postal žrtev kapitala in njegovih zakonov.

Nič čudnega, saj je naše početje popolnoma $\mathrm{v}$ nasprotju z znanstvenimi spoznanji o omejenosti naravnih virov in s posledicami, ki jih ima takšno početje za okolje. Kljub svarilom in jasnim znamenjem, ki nam jih daje okolje, pa politika in ekonomija nadaljujeta svojo mantro o rasti. Kar bi moralo biti sredstvo, je zdaj postalo cilj. Razlogov za to ni težko najti. Stabilnost sodobnega gospodarstva je strukturno odvisna od gospodarske rasti, in ko se rast ustavi, kot se je to zgodilo pred kratkim, politike zagrabi panika. Podjetja se bojujejo za preživetje, ljudje izgubljajo delovna mesta in včasih tudi svoje domove. Dvom o rasti kot edinem smotrnem cilju velja za razmišljanje norcev, idealistov in 
revolucionarjev. Za naše preživetje je nujno, da si to vprašanje vendarle zastavimo in čim prej najdemo odgovor nanj, kajti mit o rasti je na cedilu pustil dve milijardi ljudi, ki živita z manj kot dvema dolarjema na dan, in ekosistem, od katerega je odvisno naše preživetje. Propadel je v svojem bistvu, tj. zagotavljanju gospodarske stabilnosti in varnega preživetja ljudi.

Današnja ekonomija ni kos izzivom, pred katere smo postavljeni zaradi lastnega neodgovornega ravnanja; onesnaženje zraka, vode in zemlje, izguba biotske raznovrstnosti, krčenje tropskih gozdov, neprimerno ravnanje $\mathrm{z}$ odpadki ter globalno segrevanje ozračja. Potrebne so korenite spremembe. Da bi se izognili najbolj črnemu scenariju, je potreben najprej miselni (teoretični) in nato dejanski (praktični) preskok od kvantitativne h kvalitativni rasti - pri čemer moramo nujno začeti upoštevati omejitve okolja. Narava nima cene in narave ne moremo vrednotiti kot blago. Če tega ne bomo storili, nam grozi kriza, ki bo veliko obsežnejša od današnje ekonomske - grozi nam razkroj našega okolja.

Pred celotno človeštvo, sodobno znanost pa tudi politiko se postavljajo nova vprašanja in novi izzivi, ki jih bo treba reševati znotraj prevladujočega produkcijskega načina. Če bomo še naprej ignorirali resnico o zakonu entropije in njegovi vlogi, v okviru katerega si oblikujemo svojo predstavo o fizičnem, bomo tvegali lastno izginotje (Rifkin, 1980). Rifkin v razumevanju tega sveta ugotavlja tri možne relacije:

a) da obstajajo fizične meje, s katerimi je človekovo delovanje $v$ tem svetu omejeno,

b) entropijski zakon je velikanski kozmični zapor, iz katerega ni mogoče pobegniti, in

c) entropijski zakon je resnica, ki nas dela svobodne.

Entropija pomeni nepovratne spremembe stanja energije v drugo obliko, ki ni več sposobna opravljati dela. Ne samo termodinamični, ampak vsi evolucijski procesi so v bistvu nepovratni.

Jasno je, da je del okoljskih problemov sodobne civilizacije po svojem izvoru družbeno antropo- loški. Človek ne izstopa samo kot njihov vzrok, ampak v končni posledici tudi kot njihova žrtev. Poleg zdaj prevladujočih antropogenih vzrokov obstajajo za ekološke/okoljske spremembe tudi naravni vzroki. Družbeno je prekrito in zakrito z naravnim. Dejstvo, da se družbeni, antropogeni vzroki predstavljajo kot naravni vzroki za okoljske probleme, vpliva na zmanjšanje družbene okoljske previdnosti in preventive. Družba se zaveda nevarnosti globalne ekološke krize, iščejo se različni izhodi in predlagajo se rešitve, ki pa so praviloma v nasprotju s težnjo eksponencialne gospodarske rasti.

Toda ne glede na to, da današnja ekološka kriza s stališča zemeljskih in še bolj kozmičnih zakonitosti nima takih razsežnosti, kot ji jih pripisujemo, ta vsekakor povzroča zaskrbljenost tako ekonomistov kot ekologov. Ker tudi različne študije o mejah rasti, kot so Meje rasti (LTG), Ocene tisočletja (MA), Indeks okoljske trajnosti (ESI) in Indeks okoljske uspešnosti, (EPI), niso optimistične, se mrzlično iščejo ekonomski, pravni in moralno etični vzvodi za izhod iz krize. Tudi vsa dosedanja okoljska in v glavnem naravovarstvena politika $v$ bistvu temelji na pragmatičnih, instrumentalnih, antropocentričnih vrednotah. Še vedno je namreč bolje, da je varstvo okolja in narave antropocentrično, kot pa da sploh ne obstaja. Nadaljnji radikalni korak je intrinzična ekološka etika, ki zahteva varovanje in spoštovanje naravnih bitnosti zaradi njih samih in ne samo zaradi morebitnih človekovih ekonomskih, spoznavnih, estetskih, medicinskih in psiholoških koristi.

Temeljno protislovje med naravo in človekom se tako nadaljuje. Gre za nasprotje med načinom, po katerem deluje narava, in načinom, ki je najbližji človeku in v okviru katerega človek porablja oziroma troši. Do narave se človek obnaša kot do bolnika: misli, da naravo zdravi, sočasno pa jo upravlja in nadzoruje. Medtem ko si prizadeva podaljšati obstoj družbe, negativno vpliva na evolucijo narave. Glede na omenjeno mnogi menijo, da je največji izziv 21. stoletja prav ideja upravljanja planeta Zemlja - t. i. geomenedžment. Sem sodi tudi ideja upravljanja življenja - biomenedžment -, kar se kaže prek ciljev genskih raziskovanj (Cifrić, 2000).

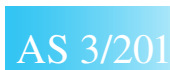


Z globalizacijo sveta se seveda globalizirajo tudi ekološke posledice. Cifrić v poglavju »Nasilje in kultura nasilja « razlikuje tri vrste nasilja: nasilje znotraj družbe, nasilje do drugih družb in nasilje do narave. Vsaka družba zase opredeli vrsto nasilja ter se v obliki vrednot, običajev ali pravnih norm bojuje proti nasilju. Skladno s tem se te vrednote vključujejo $\mathrm{v}$ izobraževalne programe (Cifrić, 2000). Isti avtor, sklicujoč se na Verbeeka, ugotavlja, da človekova potreba po spreminjanju sveta in odkrivanju nečesa novega izhaja iz njegove antropogene radovednosti in biološko kodirane potrebe po ohranitvi. Obe dimenziji, tako biološka kot sociokulturna, sta predpostavki za ekološki etos, v katerega sta vgrajena tako občutek neodvisnosti in samoodgovornosti kot tudi upoštevanje pomena narave. Čeprav nam prekratek življenjski ciklus ne omogoča empirične evolucijske izkušnje, je treba verjeti prizadevanjem, ki delujejo v smeri, da bi s pomočjo znanosti predvideli možne scenarije razvoja življenja na planetu.

Po zaslugi take ekonomije in njenega produkcijskega načina v času krize živimo kot v nekem »družbeno naravnem stanju «. Kriza zadeva predvsem človekovo antropološko dimenzijo bivanja. V nekem smislu je človek vedno živel v nekakšni krizi, le da je današnja kriza postala globalna, planetarna. Sodobna znanstvena odkritja in tehnični napredek so velik izziv za biološko evolucijo. Človek je naravne meje zanesljivo prekoračil zlasti z dvema odkritjema - to sta delitev atomskega jedra in »vdor « v genom. O uporabi prvega odkritja vemo marsikaj, o posledicah uporabe drugega se šele razpravlja.

Zaskrbljenost zaradi morebitnih posledic odkritij na človeka v prihodnosti vpliva na razprave o ekološki etiki (environmental ethics, Umweltethik), pa tudi na »etiko prihodnosti «. Smo v položaju, ko je prihodnost mogoče vse manj predvideti ne glede na dejstvo, da nenehno nastaja vedno več znanstvenih spoznanj (Cifrić, 2000). Ne pomaga niti to, da imamo že več deset let tudi znanost o znanosti, torej poskus kritičnega presojanja znanosti same in njenih vplivov na človeka, družbo in okolje. Človek je prišel v neko temeljno protislovje s samim seboj. Človek kot bitje prihodnosti oziroma bitje za prihodnost, kot ga je opredelil že Aristotel, je prišel v konflikt s svojo prihodnostjo in jo tudi v temeljih ogroža oziroma je prihodnost ogrožena ravno od človeka samega.

\section{KJE ISKATI GLOBLJI IZVOR ZA TEŽAVE SODOBNE EKONOMIJE?}

Filozofi vidijo vzroke za potrebo po stalni rasti gospodarstva v globinah človekove duše oziroma človeške narave same. Človek se nenehno čuti dolžnega storiti nekaj za zanesljivejšo prihodnost. Stalno ga prežemata tesnoba in strah pred prihodnostjo. Toda od kod jemljemo kriterij za izvorni eksistencialni smisel tega »čutiti se dolžnega «? Iz tega, da »dolžan « vznikne kot predikat za »jaz sem«. (Heidegger, 1997). Bit tubiti je skrb. Skrb obsega v sebi faktičnost (vrženost), eksistenco (zasnutek) in zapadlost. Kot bivajoča je tubit vržena v ta svet, ni pa privedena $v$ svoj tu sama od sebe. Bivajoča tubit je določena kot zmožnost biti, ki pripada njej sami in je vendar ni dala sebi v last kot ona sama (prav tam: 387). Skrb sama je v svojem bistvu vseskozi prepojena z ničnostjo. Bivajoče, ki smo vselej mi sami, je ontološko najbolj oddaljeno. Vzrok za to tiči vselej v skrbi. Skrb je bit $k$ smrti. Tesnoba je vzpostavljena prek prihodnosti (Heidegger, 1997).

Ekonomija in z njo povezane okoljsko-ekološke težave imajo torej globlje korenine $\mathrm{v}$ bistvu biti same in bivajočega. Šele ko bo bivajoče spoznalo, da pretirana skrb (strah) za prihodnost lahko ogrozi tudi bivajoče samo, bo morda prišlo do kopernikanskega preobrata homo economicusa. Morda pa bo novi etiki res uspelo privesti človeka do spoznanja, da ekonomija ne sme določati zavesti, in da morda, v nasprotju s Protagorasom, človek ne sme postati merilo vseh stvari (homo metron). Upati je, da še pravočasno. 
Sekularizirana družba spreminja sakralno v profano stvar, a nekatere materialne, profane stvari povzdigne na stopnjo svetosti (Cifrić, 2000). Tudi v odnosu človeka do narave se dogajajo podobne stvari, desakralizacija narave pelje v njeno še večjo degradacijo. Podobno ugotavlja Kirn, ki zapiše, da postnormalna znanost ni vrednot prosta in etično nevtralna (Kirn po Funtowitz 1993, 2008).

Stopnjevanje zavedanja o slabšanju stanja okolja je spodbudilo tudi nastanek Poročila svetovne komisije za razvoj (t. i. Brundtlandina komisija), ki je v svojem poročilu Our Common Future poudarila, da ekonomskega razvoja ni mogoče ločevati od okoljskih temeljev. V poročilu je predstavljen koncept »... trajnostnega razvoja (angl. sustainable development), ki naj bi zadovoljil potrebe sedanje generacije, ne da bi pri tem omejil razvojne možnosti prihodnjih « (The World Commission on Environment and Development, 1987).

V letu 1991 je publikacija Caring for the Earth: A Strategy for Sustainable Living, ki so jo izdale organizacije World Conservation Union (IUCN), United Nations Environmental Programme in World Wide Fund For Nature (WWF), k že omenjeni definiciji trajnostnega razvoja dodala še misel, da »trajnostni razvoj pomeni izboljšanje kakovosti človekovega življenja znotraj naravne sposobnosti podpornih ekosistemov.«(UNESCO, 2004.)

Ohranitev narave je torej imperativ družbenega in ekonomskega obstoja. Očitno je, da so mnoga naravna področja popolnoma degradirana ter so mnoge živalske in rastlinske vrste že izumrle. Ohranitev celotne narave je na taki stopnji ekonomije izključena, smiselno in nujno pa je ohraniti vsaj nekatera področja (naravni rezervati) ter čim več prave divjine. Zaščitena območja imajo zato nesporno pomembno vlogo v ohranjanju biotske pestrosti. Takih območij je v svetu prek 100 tisoč in pomenijo 11,7 odstotka površine kopnega, a njihova usoda je tesno povezana s stanjem okolja, ki jih obdaja. Stanje tega okolja je odvisno od stopnje njegove degradacije, ta pa tudi od stopnje razvitosti ekološke zavesti.

Tudi s tega vidika je pojav ideje o trajnostnem razvoju kot izhodu iz ekološke krize pomemben, ravno tako je pomembnih več različnih pojmovanj splošnega ali globalnega razvoja. Cifrić, ki navaja Bruckmeierja, ugotavlja, da so ideje o trajnostnem razvoju, zlasti tiste, ki so se ukvarjale s svetovno ekološko strategijo, doživljale evolucijo ciljev. Ti so se gibali vse od pojma »zaščite okolja« ter saniranja ekoloških posledic in vzrokov (World Conservation Strategy) do razvojnih ciljev (Ekodevelopment) in trajnostnega razvoja (Sustainable Development) (Cifrić, 2000).

Ni pomembno samo, koliko dobrin in storitev je iz določene količine energije in materialnih virov mogoče dobiti, ampak je enako pomembno tudi, koliko entropije se proizvede oziroma ekonomsko nekoristnih in ekološko škodljivih stvari. Če ne upoštevamo samo koristi, ampak tudi entropijo, potem lahko na ekonomski, tehnološki in človeški napredek gledamo povsem drugače (Kirn, 2000).

Definicija trajnostnega razvoja mora upoštevati sposobnost ekosistemov Zemlje in njihovo samoobnovitveno sposobnost. Upravljanje omejenega naravnega kapitala naj bi opredeljevalo upoštevanje treh temeljnih pravil, ki jih povzemam po Plutu:

a) stopnja rabe obnovljivih virov ne sme preseči njihove stopnje obnavljanja,

b) stopnja rabe neobnovljivih naravnih virov ne sme preseči stopnje zamenjave $\mathrm{z}$ obnovljivimi,

c) stopnja različnih emisij (in odpadkov) ne sme preseči absorpcijske (nevtralizacijske) zmogljivosti okolja (Plut, 2002).

V Riu de Janeiru so leta 1992 voditelji držav, zbrani na svetovni konferenci ZN o okolju in razvoju, program trajnostnega razvoja podrobneje opredelili z Agendo 21, ki zahteva upoštevanje načela trajnostnega razvoja in akcijski 
načrt za njegovo uresničevanje (United Nations, 2005). Svetovni vrh o okolju in razvoju je v Riu de Janeiru po dveh desetletjih dosegel globalno sprejet dogovor o potrebi novega modela razvoja. Slabi rezultati po svetovni konferenci v Riu pa so po mnenju sodelavcev Worldwatch Institute posledica neprimernega pristopa vlad in posameznikov k reševanju problemov v zvezi z rastjo prebivalstva, izgubljanja biotske raznovrstnosti ali s podnebnimi spremembami. Neučinkovitost teh prizadevanj je žal v veliki meri potrdil tudi svetovni vrh o okolju in razvoju v Johanesburgu leta 2002 (Plut, 2003).

Trajnostni razvoj je vendarle postala ideja razvoja človeške družbe, s pomočjo katere bi se izognili nevarnostim, ki jih povzroča osredotočenje na količinski materialni razvoj z izčrpavanjem naravnih virov in onesnaževanjem okolja. S trajnostnim razvojem naj bi se ohranjala tudi biološka raznovrstnost oziroma pestrost. Krovni pojem trajnostnega razvoja obsega še več drugih vidikov, ne nazadnje tudi možnosti razvoja vsakega človeka ali združbe, če ta ne škoduje drugim. Vsekakor pa naj bi trajnostni razvoj zadovoljeval potrebe sedanjega človeškega rodu, ne da bi pri tem ogrozili možnosti obstoja in razvoja prihodnjih rodov. Sprašujem se, ali je to res mogoče. Katere so tiste potrebe in koliko časa lahko še zadovoljujemo sedanje potrebe?

Po vrhu Združenih narodov 2005 povzemam Strategijo trajnostnega razvoja, ki obsega tri stebre:

- gospodarski in

- socialni razvoj ter

- varstvo okolja.

Trajnostni razvoj povezuje skrb za nosilnost naravnih sistemov in socialne izzive, s katerimi se sooča človeštvo. Že leta 1970 so »trajnost« uporabili za opis gospodarstva »V ravnovesju z osnovnim ekološkim sistemom podpore«. Ekologi so opozorili na omejitev rasti in - z namenom najti odgovor na okoljska vprašanja - predstavili alternativo »stabilne- mu stanju gospodarstva«. Področje trajnostnega razvoja je mogoče konceptualno razdeliti na tri sestavne dele:

- okoljska trajnost,

- gospodarska vzdržnost in

- družbenopolitična trajnost.

Publikacija Rachel Carson Silent Spring iz leta 1963 oznanja, da je uporaba pesticidov, kot je DDT, z vplivi na živali, rastline, ekosisteme in človekovo zdravje sprožila nastanek nove generacije mislecev in aktivistov, ki so argumentirano zahtevali socialne in politične spremembe skupaj z mirovnimi gibanji, gibanji za človekove pravice, pravice žensk itd. Vsi vztrajajo pri novi viziji prava in legalnih struktur. Vsesplošno prepričanje o nujnih temeljnih spremembah je potrebovalo novo razumevanje vrednot in premislek o ustrezni organiziranosti človekove družbe.

$\mathrm{V}$ znanstvenih ustanovah so humanisti in sociologi prepoznali klic časa in ob reševanju vprašanja, kaj lahko vpliva na razumevanje okoljske krize, odgovorno vstopili v nova področja raziskovanja v sociologiji, politiki, pravu, ekonomiji. Odslej je bila okoljska etika veliko bolj pod vplivom moralnih temeljev za zaščito in koristi preostale narave, moralne fundacije za ogrožene vrste in etične baze za obnovitev degradiranega okolja. Pojavijo se zametki intrinzične ekološke etike. Ni torej slučajno, da okoljska etika kot prepoznano področje znotraj filozofije vstopa v tretjo dekado.

\section{KAKŠNE SO MOŽNOSTI ZA IZHOD IZ KRIZE?}

Že omenjene študije, kot so Meje rasti (LTG - The Limits to Growth), Ocena ekosistemov tisočletja (MA - Millenium ecosystem assessment), Indeks okoljske trajnosti (ESI - Environmental Sustainable Index) in Indeks okoljske uspešnosti (EPI - Environmental Performance Index), odmišljajo vpliv sodobne kapitalistične oblike lastnine in produkcije na naravo/ okolje. Vse študije razen študije Meje rasti so 
umeščene znotraj paradigme ekonomske rasti. Računalniški scenariji v Oceni tisočletja zaradi sprememb v ekosistemih, ki jih je povzročila ekonomska rast, ne vodijo $\mathrm{k}$ dramatičnemu upadu človeške blaginje. V scenarijih ni upoštevana predpostavka o mejah ekosistemov in njihovih storitvah, ki praviloma trajne ekonomske rasti ne dopuščajo. $\mathrm{V}$ tem je bistvena razlika med Mejami rasti in Oceno tisočletja. Študiji ESI in EPI sta usmerjeni bolj upravljavsko kot LTG in MA, čeprav tudi slednji dve poudarjata nujnost sprememb in ukrepov za prehod k ekosocialni, trajnostni družbi.

Vsi štirje scenariji MA predvidevajo hitre spremembe $\mathrm{v}$ ekosistemih $\mathrm{v}$ prvi polovici 21. stoletja, in sicer $\mathrm{v}$ glavnem zaradi razširitve poljedelstva, mest in infrastrukture. MA meni, da raven prihodnje biološke pestrosti na Zemlji ne bo določalo samo utilitarno, antropocentrično razmišljanje o koristnosti za človeka, ampak tudi razmišljanje o intrinzični (lastni) vrednosti vrst. Pomen biološke pestrosti za prožnost in trajnost ekosistemov bi se lahko primerjal $\mathrm{z}$ vlogo generičnih tehnologij v tehničnih revolucijah. V zmanjšanju biološke pestrosti tiči velika nevarnost za človeško blaginjo, ker se trgajo »niti« v »mreži življenja«, s katero je človeško življenje oziroma celotna družba evolucijsko in ontološko povezana.

Vpliv ekosistemskih storitev na človeško blaginjo je posredovan s tehnologijo in institucijami. MA ugotavlja dvotirnost znanstveno-tehničnega napredka in učinkov ekonomske rasti. Pravi, da je tehnični napredek v državah v razvoju v zadnjih 40 letih silno povečal pridelek pšenice, riža in koruze, toda obenem povzročil degradacijo ekosistemskih storitev. Ker sta človeška blaginja in človeška identiteta povezani s tehnološkim napredkom oziroma tehnologijo, je njeno ontološko zlo težko odkriti in priznati. Kaže se v tem, da uporaba tehnologije vodi k neželenim posledicam, še posebno zato, ker jo vodijo najbolj plemeniti moralni cilji - češ da se uporablja samo za človeško korist in blaginjo. MA pokaže, da vsak ekološki/okoljski problem ni rešljiv s pomočjo tehnologije, saj tehnološke rešitve včasih ustvarjajo nove probleme in ranljivost. Študija MA nam sporoča: biološka pestrost se zmanjšuje v vseh štirih scenarijih in zato ostaja dolgoročna trajnost negotova. Ta negotovost je ključnega pomena in je v prid temeljnim ugotovitvam iz LTG. MA veliko pričakuje od zaščitenih območij. Zaščitena območja imajo pomembno vlogo pri varovanju biološke pestrosti.

Tudi pregled stanja biotske raznovrstnosti in krajinske pestrosti v Sloveniji potrjuje podobne težnje, čeprav so manj izraziti kakor v razvitih srednjeevropskih državah. Ogroženih je denimo 10 odstotkov vseh praprotnic in semenk ter 56 odstotkov vretenčarjev (sesalci, ptiči, plazilci, dvoživke, ribe), najbolj ogroženi habitatni tipi pa so podzemski, obalni in morski, stoječe in tekoče vode, suha in vlažna travišča. Med domorodnimi pasmami domačih živali je v kategoriji ogroženih populacij v Sloveniji najmanj devet pasem. Slovenija ima v primerjavi z državami Evropske unije še več območji z ohranjenimi habitatnimi tipi, ki nastanejo kot posledica ekstenzivne kmetijske in gozdarske rabe.

Ocena UNEP-a potrjuje, da je $\mathrm{v}$ nekaterih evropskih državah pri skupinah, kot so metulji, ptice in sesalci, izumrlo ali izginilo do 24 odstotkov vrst. Evropska okoljska agencija (EEA) v svojih poročilih navaja, da so vzroki za zmanjševanje biotske raznovrstnosti v mnogih evropskih regijah predvsem intenzivne, deloma industrijske oblike kmetijske in gozdarske rabe prostora, visoka stopnja fragmentacije ostankov naravnih habitatov kot posledica infrastrukture, urbanizacija, množični turizem ter onesnaženost vode in zraka. Pri sedanjih trendih gospodarske rasti se bo izguba biotske raznovrstnosti v Evropi bržkone nadaljevala. Ulrich Beck poskuša iz ekološke situacije naše civilizacije, zlasti iz novih tipov globalnih ekoloških tveganj, oblikovati novo teorijo družbe in politike, ki jo je poimenoval »družba tveganja« (Beck, 2009 ). 
Ogroženost biotske raznovrstnosti izhaja iz človekovega odnosa do narave in obstoječih vedenjskih vzorcev v družbi. Za družbeni razvoj je pomembno raziskovanje konceptov in načinov trajnostne rabe sestavin biotske raznovrstnosti. Skoraj sočasno pa se je človeštvo znašlo še pred eno resno nalogo, in sicer kako omiliti dosedanje negativne učinke podnebnih sprememb na okolje. Opaziti je, da večji del skrbi izhaja iz strahu, kakšne bodo posledice podnebnih sprememb za človeštvo, zelo malo pa je čutiti zaskrbljenost, kaj bo z drugimi rastlinskimi in živalskimi vrstami (antropocentrična drža).

Stabilizirati podnebne spremembe in ohranjati biotsko raznovrstnost bo možno le, če se bo celotna družba zavedala vzrokov in posledic lastnega ogrožanja in bo sposobna spremeniti dobršen del svojih razvad, navad in vedenjskih vzorcev. To bo mogoče doseči ob motivaciji z ustreznimi mehanizmi, z omejitvami in spodbudami ter primerno informiranostjo, ozaveščenostjo in izobraževanjem, za kar morajo poskrbeti vsi trije segmenti oblasti. Vsekakor postaja zelo aktualno vprašanje oblikovanja naravovarstvene ali ekološke zavesti, ki kot tema (kako oblikovati ekološko zavest) še vedno nastopa $v$ številnih znanstvenih razpravah, predvsem na področju ekološke/okoljske etike. Vsem štirim scenarijem v MA je skupno naslednje: človeška raba ekosistemskih storitev se bo v prihodnjih 50 letih povečevala, hkrati se bo povečevala produktivnost nekaterih storitev, da bomo zadostili povpraševanju. Izredno pomembna je ugotovitev MA, da izboljšanje in poslabšanje ekosistemskih storitev vpliva na celotno človeško blaginjo, vključno s temeljnimi materialnimi potrebami za dobro življenje, zdravje, dobre družbene odnose, varnost, svobodo izbire in delovanje.

Vsi ukrepi MA, EPI, ESI nedvomno dopušča- jo, da je degradacijo narave znotraj paradigme rasti in kapitala možno zmanjšati ali celo preprečiti. Samo LTG predpostavlja najbolj reformiran ekokapitalizem, tj. nerastoči kapital. Slovenijo neposredno zadevata ESI in EPI, saj jo vključujeta v svojo analizo. V ESI je Slovenija izmed 146 držav uvrščena na 29. mesto, v EPI pa je med 133 državami na 31. mestu.

Raziskave niso optimistične; kažejo, da človeška poraba vseh ekosistemskih storitev hitro raste (MA: 39) in se s težnjo kapitala po nenehnem razširjanju reprodukcije povečuje. MA kot glavne dejavnike za degradacijo ekosistemov in njihovih storitev navaja: rast števila prebivalstva, povečanje udobja, spremenjen način življenja ter ekološko neustrezne tehnologije. Mar ni z rastočimi zahtevami povezana tudi težnja kapitala po rasti in profitu? Te zahteve so odvzele sredstva mnogim oblikam življenja na Zemlji in degradirale mnoga bivališča. Človeška oblika življenja izrinja in uničuje druge. Tudi EPI (Environmental Performance Index) ugotavlja, da se pestrost življenja hitro zmanjšuje, čeprav se je stanje okolja ponekod v razvitih državah po nekaterih drugih kazalcih izboljšalo. MA poudarja, da se pomenu lastnine priznava višja vrednost kot naravnim virom, ki jih ne dojemamo kot svobodne in brezmejne ter jim ne priznavamo njihove polne vrednosti. Če torej ne bomo spremenili razmišljanja o naravnih virih, znanja in tehnologije, ki že zdaj omogočajo zmanjšanje človekovih vplivov na ekosisteme, ne bodo mogli biti polno izkoriščeni. Naravni viri bodo po mnenju MA zaščiteni le, če bodo imeli lastnike in bodo ljudje, vključeni v odločitve, ki zadevajo vire, deležni njihovih koristi. Dejstva o tem, da naravni viri in ekosistemske storitve niso neomejene dobrine in jim moramo priznati polno vrednost, so združljiva z ekokapitalizmom. Vse študije pa ugotavljajo, da je produktivnost ekosistemov odvisna od izbora politik in inoviranja, trgovine, sistemov obdavčenja in reguliranja. Študije MA, ESI, EPI predpostavljajo in sprejemajo ekološko reformiran kapitalizem rasti, 
LTG pa ekološko reformiran nerastoči kapitalizem. LTG je izredno kritična do eksponencialne ekonomske rasti, MA, ESI in EPI pa niti ne. Samo pri LTG je jasno, da paradigma rasti vodi v katastrofo. Tej usmeritvi je edina alternativa ekosocializem, ki ne spoštuje samo mej rasti, ampak sprejema tudi tržnost, inovativnost in demokratičnost.

Tudi računalniški scenariji, ki raziskujejo možna prihodnja razmerja med naravo/okoljem in družbo, izdelani v že omenjenih študijah, so pokazali, da bodo v prvi polovici tega tisočletja pritiski na ekosisteme še naraščali. Rast človeške uporabe vseh ekosistemskih storitev je bila v drugi polovici 20. stoletja na splošno počasnejša od gospodarske rasti, a je vseeno naraščala.

MA sodi, da so ekološka presenečenja zaradi omejitve v sedanjem razumevanju posamičnih lastnosti ekosistemov neizogibna. Ne vemo pa, kakšna presenečenja nas čakajo. Tako v njej piše, da obstaja sicer nepopoln dokaz, da spremembe, povzročene v ekosistemih, povečujejo verjetnost nelinearnih sprememb s pomembnimi posledicami za človekovo blaginjo. Večina ekosistemskih sprememb je sicer postopnih (linearnih), toda srečujemo se tudi $\mathrm{z}$ nelinearnimi, ki vključujejo pospešitve in nenadne nepovratne spremembe (MA: 88). Spremembe se začnejo dogajati veliko prej, kot jih opazimo, res pa je, da se jih ustrašimo šele takrat, ko so nevarne za človeka in ne za ekosistem. Uspavajoče je namreč misliti, da nam vse do sprožilnih prelomnih točk gre dobro.

Vneti zagovorniki ekonomske rasti že dolgo časa zatrjujejo, da je z rastjo vse v redu. $R e$ sni problemi nastopijo, če je gospodarska rast majhna, ničelna ali celo negativna. Pri tem pa najpogosteje spregledajo ekološke obremenitve kot posledice ekonomske rasti, še zlasti nelinearnost, ki s časovnim zamikom sledi neproblematičnim, kontinuiranim in pogosto povsem neopaznim spremembam. Potreben je klic k čuječnosti, ne pa k usodno zavajajočemu optimizmu rasti.
Od uspešnosti okoljskih politik in individualne ekološke ozaveščenosti, delovanja v smeri prehoda k ekosocialni trajnostni družbi in trajnostnemu razvoju ter od začetka tega prehoda bo odvisno, ali bo prehod trd, dramatičen, ekološko fizično izsiljen ali pa mehak in izpeljan na družbeno premišljen način.

Mesarović (1974) je napovedal, da se bo po letu 2002 uresničeval scenarij svetovne nestabilnosti, ki prehaja v scenarij nespoštovanja okoljskih omejitev in bo prešel $\mathrm{v}$ poostren varnostni režim ter ekodiktaturo bogatih nad revnimi, šele za tem se bo zgodil obrat k ekosocialnemu tržnemu gospodarstvu. Vsekakor je potrebno resno upoštevanje koncepta meje rasti, ne glede na metodološke pomanjkljivosti modela - te so: nezanesljivost podatkov in izpuščanje pomembnih razsežnosti realnosti, kot so razmerje med bogatimi in revnimi, cenovni mehanizem, vloga mednarodne solidarnosti, religij in svetovnih nazorov pri reševanju globalnih problemov človeštva. Bistvena omejitev je čas.

\section{KAKO LAHKO IZOBRAŽEVANJE PRIPOMORE K REŠEVANJU TEH TEŽAV?}

Pri razreševanju težav, ki jih je nakopičil sodobni produkcijski način življenja, se veliko pričakuje od izobraževanja. Mnogi menijo, da bi spremembo človekovega odnosa do narave najlaže dosegli s primernim izobraževanjem. Že konferenca v Riu je v dokumentu Agenda 21 dala večji pomen izobraževanju, ki mora več prispevati $\mathrm{k}$ spremembi obnašanja in oblikovanju novih vrednot ter odnosu ljudi do okolja.

Svetovni izobraževalni forum v Dakarju skupaj z univerzalno deklaracijo o človekovih pravicah je leta 2000 v svetovni Deklaraciji o možnosti izobraževanja za vse utemeljeval izobraževanje kot temeljno človekovo pravico in ključ do trajnostnega razvoja, miru in stabilnosti, socialne in gospodarske rasti ter tudi razvoja narodov (UNESCO, 2004). Združeni narodi so decembra 2002 obdobje od 2005 do 
2014 razglasili za desetletje vzgoje za trajnostni razvoj in organizacijo UNESCO določili kot vodilno pri razširjanju in implementaciji tega spoznanja.

Evropska komisija ZN je na konferenci v Kijevu 2003 poudarila potrebo po izboljšanju izobraže-

Z izobrazbo se stopnjujeta okoljska kritičnost in občutjivost. valnih sistemov, ki bi razširjali splošno razumevanje in uveljavljanje trajnostnega razvoja. $\mathrm{Na}$ podlagi teh sklepov je bil izdelan dokument Draft Framevork for the Decade of Education for Sustainable Development, ki so ga pripravljali člani agencij ZN, narodnih vlad, civilne družbe, nevladnih organizacij, izvedenci in specialisti (UNESCO, 2004). Ohrabrujoče je spoznanje, da javnomnenjske raziskave kažejo na izobrazbo kot statistično pomembno spremenljivko. V odnosu do okoljske zavesti in praktičnega okoljskega vedenja se to docela potrjuje. $\mathrm{Z}$ izobrazbo se stopnjujeta okoljska kritičnost in občutljivost (Kirn, 2003). V UNESCO-vem programu Desetletje za trajnostni razvoj (United Nations Decade of Education for Sustainable Development 2005-2014) zasledimo najnovejše smernice za vzgojo za trajnostni razvoj. Temeljni cilj tega desetletja $\mathrm{v}$ smislu vzgoje za trajnostni razvoj je »... svet, kjer naj ima vsak posameznik možnost učenja vrednot, vedenja in življenjskih navad, ki so potrebni za pozitivno pretvorbo družbe, ki je nujna za zagotovitev trajnostne prihodnosti.«(UNESCO, 2004.) Trajnostni razvoj je osredotočen na odnose med ljudmi in njihovim okoljem.

Vsaj deloma imajo prav tisti, ki med vzroke za sodobne ekološke/okoljske probleme prištevajo tudi neustrezno izobraževanje, ki naj bi bilo premalo »ekologizirano«. Mladi sodijo med tisti del populacije, ki nekatere okolju prijazne ugotovitve podpirajo - tudi demografski redukcionizem. Z izobrazbo se širi zaznavanje nevarnosti, a ne nujno tudi sama etična drža (Kirn, 2003). Obstoječa ekološka/okoljska zavest $\mathrm{v}$ svetu in pri nas dosedanje polje moralnih objektov razširja tudi na rastline, živali in naravo. Glede na to, da se taka etika utemeljuje in upravičuje z instrumentalno, pragmatično, antropocentrično držo, je vprašanja o oblikovanju moralno-etičnih vrednot smiselno vključevati v izobraževalni sistem.

Raziskave javnega mnenja kažejo, da so mlajše generacije dovzetnejše za stališča, ki so v prid varovanju okolja. Doseganje odgovornejšega ravnanja $\mathrm{z}$ okoljem pa je ne nazadnje tudi normativna naloga vzgojno-izobraževalnega sistema. Vprašanje, kolikšen je lahko vpliv izobraževanja na oblikovanje stališč in vrednot s poudarkom na naravovarstvenih ciljih, seveda še naprej ostaja odprto. Raziskave javnega mnenja so namreč pokazale, da sta si vpliv izobrazbe in starosti na okoljsko držo in ozaveščenost pogosto nasprotna. Razlika med starejšimi in mlajšimi je ta, da mlajši dosti manj soglašajo $s$ trditvijo, da za okolje ne moremo kaj dosti narediti. Prav tako se mlajši manj strinjajo s trditvijo, da ni smiselno skrbeti za okolje, če tega ne počnejo vsi. Nesporno pa je, da so ekološko/ okoljske značilnosti zavesti Slovencev pomemben dejavnik pri preoblikovanju zdajšnjega okolju neprijaznega ravnanja tako na individualni, podjetniški kot tudi nacionalni ravni. V ekološki zavesti Slovencev na pragu tretjega tisočletja je zaznati instrumentalno, pragmatično in, vsaj deklarativno, tudi vrednostno intrinzično ekološko držo, ki pripisuje vrednost naravnim bitnostim ne glede na človekovo korist. Za doseganje odgovornejšega ravnanja $\mathrm{z}$ okoljem oziroma vzorca ravnanja je pomembno spoznanje o lastni soudeležbi pri nastajanju okoljskih posledic.

Pomembno je torej zaznavanje nevarnosti onesnaževanja in degradacije okolja za sebe in druge. Ozaveščenost o globalnosti mnogih ekoloških/okoljskih problemov je eden izmed duhovnih pogojev za njihovo uspešno reševanje.

\section{IE REŠITEV MORDA V NOVI EKOLOŠKI ETIKI?}

Že na začetku se postavi vprašanje, ali je na antropogeno pogojeni ekonomiji mogoče gra- 
diti novo etiko. Bistva bivajočega, ki teži k samoohranitvi in pretirani skrbi ter strahu pred prihodnostjo, ni mogoče povsem zanikati. Odkar so lokalni problemi postali problemi globalnih razsežnosti, njihovi vzroki pa mnogo bolj kompleksni in sinergetični, je »obrat «k raziskovanju $\mathrm{v}$ smeri javne percepcije in občutljivosti opaznejši. Že pred več kot 30 leti so se pojavile nove ideje in vrednote oziroma nov pogled na svet, t. i. »nova okoljska paradigma « ali še pogosteje imenovana »nova ekološka paradigma (Dunlap in drugi, 2000). Etika se je prvenstveno začela sistematično ukvarjati prav $\mathrm{z}$ raziskovanjem stališč, vrednot in prepričanj ljudi v odnosu do okolja. Javnomnenjske raziskave kažejo tudi, da obstajajo možnosti vplivanja na oblikovanje intrinzične etike - etike, ki tudi drugim bitnostim priznava pravice ne glede na to, kakšen pomen imajo za človeka. Vplivati bi bilo treba na stališča in vrednote mladih ter zanje izdelati skale za ugotavljanje nove ekološke paradigme, ki naj bi izhajala iz ekologiji naklonjenega vedenja mladih. To vedenje vključuje tudi in predvsem varstvo narave in vsega tistega, kar je $\mathrm{z}$ njo povezano.

Ponekod obstaja velik delež neodločenih, ki so se odločili za modaliteto »niti-niti«. Ti nekaterih okoljskih problemov ne razumejo polarizirano ali na način »črno-belo«, ampak imajo bolj pretanjen pogled na probleme. Mlajši, neverujoči in bolj izobraženi praviloma bolj izkazujejo okolju prijazna stališča in imajo izrazitejšo aktivistično držo (Kirn, 2003).

Moramo se seveda vprašati, ali nastanek pojma »svetovni ekološki etos« ni morda zgolj nova ideja ohranjanja dominacije obstoječe ideologije in »trajnostnega razvoja«. Če se bo obdržala ekonomska paradigma rasti, bomo iskali samo formulo za začasni izhod iz enega od »neprimernih« ekonomskih modelov in s tem pripomogli k razvoju nove zgodovinske krize. Nikakor pa to ne sme biti nova oblika zagovarjanja zdajšnjega ekonomskega in kulturnega reda.

Danes je temeljni problem odnosa človek narava v dejstvu, da je vedno več ljudi od nara- ve odvisnih le posredno. V verigi proizvodnje hrane so nekateri ljudje proizvajalci, drugi pa potrošniki. Prvi v naravi vidijo le vir sredstev za preživljanje drugih, drugi narave sploh ne vidijo, saj od nje niso neposredno odvisni. Večina ljudi naravo razume kot estetsko okolje ali prostor za rekreacijo. Le redki jo razumejo kot ekosistem z vsemi intrinzičnimi pravicami. Gre za vse bolj naraščajočo odsotnost intrinzičnega gledanja na naravo, po katerem je moralno dopustiti živeti tudi drugim rastlinskim in živalskim združbam. V tej odsotnosti lahko iščemo tudi vzroke za naraščanje tolerance do nekaterih človekovih posegov v naravo.

Ostane nam le spoznanje, da je moralna dolžnost vsakega posameznika upoštevati univerzalni zakon vesolja in gojiti tisto prakso trajnostnega razvoja, s katero lahko vsak po svojih najboljših močeh pripomore k ohranjanju okolja oziroma prostora, v katerem živi. Ne nazadnje je tudi človek del narave in vse, kar počne, oziroma njegova celotna praksa ne more biti v nasprotju s temeljnimi naravnimi procesi. Iz tega tudi sledi, da bo narava, ki je umno urejena, iz svojega sistema izločila vse tisto, kar bo delovalo ne umno oziroma v nasprotju s tako urejenim naravnim sistemom. Na razplet lahko počakamo, saj bo zadnjo besedo tako ali tako imela narava sama.

\section{LITERATURA}

Beck, U. (2009). Družba tveganja. Ljubljana: Krtina. Carson, R. (1962). Silent Spring. New York: Hougton Mifflin.

Cifrić, I. (2000). Moderno društvo i svjetski etos perspektive čovjekova nasljedža. Zagreb: Hrvatsko sociološko društvo.

Dunlap in drugi. (2000). »Measuring Endorsement of the New Ecological Paradigm: A Revised NEP Scale«. Journal of Social Issues, 56: 3.

Heidegger, M. (1997). Bit in čas. Ljubljana: Slovenska matica.

Kirn, A. (1999). Teoretične in praktične dileme ekološkelokoljske etike (gradivo).

Kirn, A. (1999). »Sličnosti in razlike med Slovenijo in Evropo pri zaznavanju in vrednotenju okoljskih 
problemov«. Anthropos, 4-6: 77-94.

Kirn, A. (2001). »Okoljska in socialna razsežnost globalizacije«. Anthropos, 4-6: 77-94.

Kirn, A. (2003). »Ekološka/okoljska zavest Slovencev na pragu tretjega tisočletja«. Teorija in praksa, 1: 17-36.

Kirn, A. (1998). »Izmedžu antropološke i ontološke opasnosti. Martin Heidegger i 'usuda biti'«. Socijalna ekologija, 4: 331-340.

Kirn, A. (1998). »Narava in morala. Človek narave nikar«. Okolje, 3-4: 12-16.

Kirn, A. (2004). Narava-družba-ekološka zavest. Ljubljana: Fakulteta za družbene vede.

Kirn, A. (2006). »Meje rasti, ocena tisočletja, indeks okoljske trajnosti in indeks okoljske uspešnosti«. Teorija in praksa, 5-6: 658-673.

Meadows. D./Meadows D. (1972). The Limits of Growth. New York: Universe Books.

Mesarovič, M./Pestel, E. (1974). Čovječanstvo na raskršču: Drugi izveštaj Rimskog kluba. Zagreb: Stvarnost.

Plut, D. (2002). »Teoretični in terminološki vidiki koncepta trajnosti/sonaravnosti«. Geografski vestnik, 1: 73-86.

Plut, D. (2003). »Uvodnik: Ravnovesje med človeštvom in planetarnim ekosistemom - ključna naloga za 21. stoletje«. Okoljska vzgoja šoli, 1: 5-6.

Poročilo o oceni ekosistemov tisočletja. Dostopno na: http://www.millenniumassessment.org/documents/ document.356.aspx.pdf

Rifkin, J. (1980). Entropy, A new world view. New York: The Viking Press. 